\title{
NITROGEN BALANCE STUDIES ON THE KEMPNER RICE DIET
}

\author{
By WILLIAM B. SCHWARTZ AND JEROME K. MERLIS \\ (From the Neuropsychiatric and Medical Services, Cushing Veterans Administration Hospital, \\ Framingham, Massachusetts)
}

(Received for publication January 5, 1948)

Current interest in the dietary therapy of hypertensive states in man has been stimulated by Kempner's reports $(1,2,3)$ of marked benefits achieved by his "rice diet." Dick and Schwartz (4) have reported that experimentally produced hypertension in dogs is favorably influenced by this regime, and Grollman and Harrison (5) have observed a significant reduction in the blood pressure of hypertensive rats fed only rice.

Kempner's "rice diet" $(1,2)$ is composed of rice, fruit, fruit juices and sugar, with vitamin and mineral supplements. He states: "Compared to diets previously used in hypertension, the ricefruit-sugar diet is rigid. It contains in 2,000 calories about $5 \mathrm{gms}$. of fat and $20 \mathrm{gms}$. of protein derived from rice and fruit . . .” (2). Fluids are usually limited to $700-1,000 \mathrm{cc}$. of fruit juices per day. No added salt is permitted. Kempner further reports: "After two months of rice diet, the nitrogen excretion in the urine averaged 2.26 gm. per 1,000 cc., $2.26 \mathrm{gm}$. in 24 hours. If an allowance of $0.9 \mathrm{gm}$. per 24 hours is made for the excretion of nitrogen other than that excreted in the urine, the total nitrogen loss in 24 hours is about $3.16 \mathrm{gm}$. With a daily intake of $3.2 \times$ $6.25=20 \mathrm{gm}$. of protein, these patients are in protein equilibrium;" (1). No analyses of food or fecal nitrogen are reported. In all Kempner's papers it appears that the standard diet used by him contained an estimated 2,000 calories. In some cases where weight loss seemed excessive the caloric value of the diet was increased. However, in 11 of the 12 representative cases reported in his papers $(1,3)$ the daily caloric intake was 2,000 calories or less. In the 12 th case, the intake was 2,400 calories. Body weights in these patients ranged from 54.0 to $93.0 \mathrm{~kg}$., and no attempt was made to adjust intake to body weight or surface area.

Since Kempner's claim that nitrogen balance is achieved on such a low intake of protein was not in accord with other data $(6,7)$ study of the ni- trogen balance of subjects on the "rice diet" was undertaken.

\section{PROCEDURE}

Six subjects were chosen for study. Four of these were psychotic adult males who showed no evidence of somatic disturbance and who were sufficiently in contact with reality to cooperate fully. The fifth subject was a patient with multiple sclerosis in remission. The sixth was a female nurse in good health who was in charge of the group throughout the day. The age, height, weight, surface area and basal caloric consumption of these subjects are given in Table I.

TABLE I

Physical characteristics and basal caloric expenditures

\begin{tabular}{c|c|c|c|r|r}
\hline \hline Subject & Age & Height & Weight & $\begin{array}{c}\text { Surface } \\
\text { area* }\end{array}$ & \multicolumn{1}{c}{$\begin{array}{c}\text { Basalt } \\
\text { calories }\end{array}$} \\
\cline { 2 - 5 } 1 & & $c m$. & $k g$. & sq. m. & \\
2 & 40 & 162.5 & 89.4 & 1.92 & -7 \\
3 & 40 & 177 & 64.5 & 1.77 & 1568 \\
4 & 31 & 174 & 73.3 & 1.69 & 1451 \\
5 & 26 & 167.5 & 70.4 & 1.85 & 1418 \\
6 & 25 & 175 & 86.9 & 2.00 & 1604 \\
& & & & $\frac{1886}{1.84}$ & aver. 1585 \\
\hline Hypertensive & 27 & 170 & 74.5 & 1.85 & 2017 \\
\hline
\end{tabular}

* Calculated according to the DuBois equation.

† Calculated from basal oxygen consumption determined with a McKesson Waterless Metabolor, by multiplying the 24-hour oxygen consumption by 4.82 .

$\$$ Repeatedly unsatisfactory.

A separate ward was set aside, and the group remained on this ward during the entire period. Reliable attendants, working in shifts, assured that the ward was continuously supervised. The subjects were ambulatory but engaged only in ward activities. All food was specially weighed and prepared in a separate diet kitchen, and no edibles other than the diet were allowed on the ward. The latrine was kept locked, and the male subjects could enter only with an attendant. This permitted rigid control of the collection of urine and feces.

The regular hospital diet, containing approximately 80 gm. of protein, was replaced by a protein-depletion diet. This diet was calculated to contain approximately 1,714 calories, with $8.4 \mathrm{gm}$. of protein (Table II-A). At the end of a four-day period on this depletion diet, the "rice diet" was introduced and was continued for eight days. 
The diet consisted of $200 \mathrm{gm}$. of rice (dry weight) with additional calories supplied by fruit, sugar and fruit juices to a total of approximately 2,289 calories per day. This provided an estimated intake of $21 \mathrm{gm}$. of protein. The only fluids permitted were the $1,000 \mathrm{cc}$. of fruit juice each day. No salt was allowed. Daily vitamin and mineral supplements were provided (Table II-B). This diet differs from the one used by Kempner in his nitrogen balance studies only in having a somewhat higher caloric value achieved by the use of a larger quantity of sucrose.

All subjects consumed the total diet each day. Twentyfour-hour urine collections were made in jars containing $5 \mathrm{cc}$. of 50 per cent nitrogen-free sulfuric acid, and aliquots were stored in a refrigerator. Feces collected throughout the eight-day period on the "rice diet" were likewise refrigerated. Carmine was used to mark the beginning and end of the collection period.

Aliquots of the 24-hour urine collection of the last day on the regular hospital diet, the final day of the depletion period, and the third, sixth and eighth days on the Kempner regime were analyzed for nitrogen. The feces for the eight-day period on the "rice diet" were pooled and homogenized in a Waring Blender, and an aliquot was analyzed for nitrogen. Diets were likewise homogenized before analysis. Nitrogen determinations were carried out by a Macro-Kjeldahl method, using the Arnold-Gunning digestion mixture and Meeker's boric acid modification for distillation (8). All analyses were made in duplicate.

A patient with severe hypertension was placed on the "rice diet" for a period of 90 days and his nitrogen bal-

TABLE II-A

Depletion diet

\begin{tabular}{l|c|c|c}
\hline \hline & Weight & \multicolumn{2}{|c}{ Calculated values } \\
\cline { 2 - 4 } & & Protein & Calories \\
\hline & $g m$. & $g m$. & \\
Cornmeal & 15, dry & 1.3 & 53 \\
Fruits, peaches, canned & 100 & .5 & 102 \\
Pineapple, canned & 100 & .4 & 87 \\
Apple, baked & 115 & .5 & 181 \\
Vegetables, tomatoes, canned & 80 & .8 & 16 \\
Carrots, canned & 100 & 1.0 & 37 \\
Celery & 25 & .35 & 6 \\
Asparagus, canned & 50 & .9 & 10 \\
String beans, canned & 50 & 1.0 & 18 \\
Turnip & 50 & .55 & 17 \\
Cabbage & 50 & .7 & 15 \\
Bouillon & 1 cube & .4 & 3 \\
& & 8.4 & 545 \\
Gingerale 24 oz. & 720 & - & 258 \\
Coca Cola 24 oz. & 720 & - & 258 \\
Sucrose* & 165 & - & 653 \\
\hline Total & & $8.4 \dagger$ & 1714 \\
\hline
\end{tabular}

* Caloric value calculated from data in Handbook of Physics and Chemistry, Chemical Rubber Publishing Co., Cleveland, 1947.

† By analysis $7.03 \mathrm{gm}$.
TABLE II-B

Rice diet

\begin{tabular}{l|c|c|c}
\hline \hline & \multirow{2}{*}{ Weight } & \multicolumn{2}{|c}{ Calculated values } \\
\cline { 2 - 4 } & & Protein & Calories \\
\cline { 2 - 4 } & $g m$. & $g m$. & \\
Rice & $200, \mathrm{dry}$ & $15.4^{*}$ & 700 \\
Juices, orange & 200 & 1.2 & 80 \\
Pineapple & 400 & 1.2 & 216 \\
Grapefruit & 400 & 1.3 & 160 \\
Fruits, apricots, canned & 130 & .8 & 119 \\
Applesauce & 200 & .4 & 160 \\
Pears, canned & 200 & .4 & 150 \\
Raisins & 15 & .3 & 45 \\
Sucroset & 166.5 & - & 659 \\
\hline Total & & $21.0 \ddagger$ & 2289 \\
\hline
\end{tabular}

* By analysis $12.0 \mathrm{gm}$.

+ Caloric value calculated from data in Handbook of Physics and Chemistry, Chemical Rubber Publishing Co., Cleveland, 1947.

$\ddagger$ By analysis $16.43 \mathrm{gm}$.

\section{Vitamin and mineral supplement}

Ferrous Sulfate, 0.6 gm.; Vitamin A, 17,000 U.S.P. units; Vitamin D, 1,600 U.S.P. units; Thiamin Hydrochloride, $5 \mathrm{mg}$.; Riboflavin, $5 \mathrm{mg}$.; Calcium Pantothenate, 10 mg.; Nicotinamide, 30 mg.; Ascorbic Acid, $100 \mathrm{mg}$.

ance also was studied. Physical characteristics of this patient are presented in Table I.

Cholesterol determinations were carried out by the method of Bloor (9). Hematocrit was determined in Wintrobe tubes after centrifuging for 30 minutes at 2,500 r.p.m. Whole blood hemoglobin was determined by the direct photometric method of Sanford, Sheard and Osterberg (10). The method of Phillips et al: (11) was used for determining total serum protein. Non-protein nitrogen determinations were carried out by the method of Folin and Wu (12). Basal caloric consumptions were determined by the use of the McKesson Waterless Metabolor and the basal metabolic rates calculated according to the standards of Aub and DuBois.

\section{RESULTS}

$\mathrm{Kjeldahl}$ analysis revealed the nitrogen content of the "rice diet" to be $2.63 \mathrm{gm}$. (16.43 gm. protein) (Table II-B), a value 22 per cent lower than that calculated from tables (13). This was due largely to the fact that the protein content of the rice (an ordinary commercial milled type) was 6.0 per cent by analysis rather than the estimated 7.7 per cent.

The urinary nitrogen excretion of the six subjects on the final day of the hospital diet, the final day of the depletion diet, and the third, sixth and eighth days of the "rice diet" are shown in Table III. The average urinary nitrogen excretion on 
TABLE III

Nitrogen excretion studies

\begin{tabular}{|c|c|c|c|c|c|c|c|}
\hline \multirow{3}{*}{ 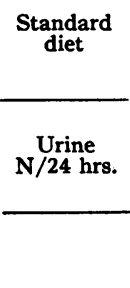 } & \multirow{3}{*}{$\begin{array}{c}\text { Deple- } \\
\text { tion } \\
\text { diet }\end{array}$} & \multicolumn{3}{|c|}{ Rice diet } & \multicolumn{3}{|c|}{ Rice diet } \\
\hline & & \multicolumn{3}{|c|}{ Urine $\mathrm{N} / 24 \mathrm{hrs}$} & \multirow{2}{*}{$\begin{array}{c}\text { Fecal } \\
\text { N/24 } \\
\text { hrs. }\end{array}$} & \multirow{2}{*}{$\begin{array}{c}\text { Total } \\
\text { final } \\
\text { out- } \\
\text { put/ } \\
24 \text { hrs. }\end{array}$} & \multirow{2}{*}{$\begin{array}{c}\mathrm{N} \\
\text { balance* } \\
\text { final } \\
24 \mathrm{hrs} .\end{array}$} \\
\hline & & $\begin{array}{l}\text { 3rd } \\
\text { day }\end{array}$ & $\begin{array}{l}\text { 6th } \\
\text { day }\end{array}$ & $\begin{array}{l}\text { 8th } \\
\text { day }\end{array}$ & & & \\
\hline $\begin{array}{c}g m . \\
\text { 1. } \quad 16.65\end{array}$ & $\begin{array}{c}g m . \\
4.51\end{array}$ & \multirow{2}{*}{$\begin{array}{c}g m . \\
\text { Menstru- } \\
\text { ating } \\
4.72 \\
4.90 \\
4.20 \\
5.90 \\
6.03\end{array}$} & $\begin{array}{l}g m . \\
3.70\end{array}$ & \begin{tabular}{l|}
$m$. \\
3.46
\end{tabular} & \begin{tabular}{|l|}
$g m$. \\
1.09
\end{tabular} & $\begin{array}{l}g m . \\
4.55\end{array}$ & $\begin{array}{c}g m . \\
-1.92\end{array}$ \\
\hline $\begin{array}{lr}2 . & 9.59 \\
\text { 3. } & 10.62 \\
\text { 4. } & 11.02 \\
5 . & 15.74 \\
6 . & 14.86\end{array}$ & $\begin{array}{l}4.26 \\
5.38 \\
6.93 \\
7.80 \\
6.80\end{array}$ & & $\begin{array}{l}3.78 \\
4.50 \\
4.20 \\
6.64 \\
6.34\end{array}$ & $\begin{array}{l}3.10 \\
4.33 \\
6.02 \\
5.87 \\
5.27\end{array}$ & $\begin{array}{r}.79 \\
1.60 \\
1.37 \\
1.06 \\
1.08\end{array}$ & $\begin{array}{l}3.89 \\
5.93 \\
7.39 \\
6.93 \\
6.35\end{array}$ & $\begin{array}{l}-1.26 \\
-3.30 \\
-4.76 \\
-4.30 \\
-3.72\end{array}$ \\
\hline Av. 13.08 & 5.95 & 5.15 & 4.86 & 4.68 & 1.17 & 5.85 & -3.22 \\
\hline
\end{tabular}

${ }^{*} \mathrm{~N}$ intake in all patients $2.63 \mathrm{gm} . / 24$ hours.

the eighth day of the "rice diet" was $4.68 \mathrm{gm}$. per 24 hours. ${ }^{1}$ The average daily fecal nitrogen excretion was $1.17 \mathrm{gm}$. The total nitrogen output (urinary plus fecal) for the final day on the diet averaged $5.85 \mathrm{gm}$. Thus nitrogen excretion exceeded nitrogen intake by $3.22 \mathrm{gm}$. per 24 hours.

The data on the hypertensive patient studied for 90 days are presented in Table IV. On the 90th day, urinary nitrogen excretion was $3.81 \mathrm{gm}$. The average daily fecal nitrogen excretion during the

TABLE IV

Hypertensive patient

90 th day of rice diet

\begin{tabular}{lr} 
Urine N/24 hours & $3.81 \mathrm{gm} . *$ \\
Feces N/24 hours & 1.49 \\
Total N/24 hours & 5.30 \\
$\mathrm{~N}$ balance & -2.67 \\
\multicolumn{3}{c}{ *30th day -4.93} & 60th day-4.64
\end{tabular}

\begin{tabular}{l|c|c|c}
\hline \hline & Initial & Final & Change \\
\hline Weight, kgs. & 71.7 & 59 & -12.7 \\
N.P.N., mg./100 cc. & 41 & 28 & -13 \\
Blood pressure, mm. Hg & $\frac{220}{130}-\frac{280}{190}$ & $\frac{140}{100}-\frac{160}{115}$ & \\
B.M.R. & +13 & +4 & -9 \\
Basal calories & 2012 & 1663 & -349 \\
Total protein, gm./100 cc. & 7.2 & 6.1 & -.9 \\
\hline
\end{tabular}

1 Ten representative urine specimens also were analyzed in the laboratory of the Department of Nutrition, Harvard School of Public Health. The results were in agreement within 2 per cent of our data. We wish to thank Dr. D. M. Hegsted for his kind cooperation. final week was $1.49 \mathrm{gm}$. Thus total nitrogen excretion was $5.3 \mathrm{gm}$. per day. In this patient, nitrogen excretion exceeded intake by $2.67 \mathrm{gm}$. per day.

Table V presents the data on blood pressure, body weight and basal metabolic rate. It will be noted that the subjects, all of whom were initially normotensive, showed, without exception, no significant change in blood pressure. Weight loss on the "rice diet" varied from 1.6 to $3.0 \mathrm{~kg}$. with an average loss of $2.1 \mathrm{~kg}$. during the eight-day period. No significant change occurred in the basal metabolic rate nor were there any appreciable changes in temperature, pulse and respiration throughout the course of the experiment except in subject number 4 who suffered an acute upper respiratory infection with fever during the fifth

TABLE V

Changes in blood pressure, weight and basal metabolic rate on rice diet

\begin{tabular}{|c|c|c|c|c|c|c|c|c|}
\hline \multirow{2}{*}{$\underset{\text { ject }}{\text { Sub- }}$} & \multicolumn{2}{|c|}{ Blood pressure } & \multicolumn{3}{|c|}{ Body weight } & \multicolumn{3}{|c|}{ Basal metabolic rate } \\
\hline & Before & 8th day & Before & $\begin{array}{l}\text { 8th } \\
\text { day }\end{array}$ & Change & Before & $\begin{array}{l}\text { 8th } \\
\text { day }\end{array}$ & Change \\
\hline $\begin{array}{l}1 \\
2 \\
3 \\
4 \\
5 \\
6\end{array}$ & $\begin{array}{l}114 / 76 \\
104 / 68 \\
128 / 74 \\
128 / 78 \\
116 / 78 \\
130 / 90\end{array}$ & $\begin{array}{l}118 / 72 \\
100 / 70 \\
122 / 72 \\
128 / 92 \\
108 / 72 \\
132 / 82\end{array}$ & $\begin{array}{c}\text { kg. } \\
89.4 \\
64.5 \\
57.7 \\
73.3 \\
70.4 \\
86.9\end{array}$ & \begin{tabular}{|c} 
kg. \\
87.4 \\
62.9 \\
56.1 \\
70.8 \\
68.5 \\
83.9
\end{tabular} & $\begin{array}{l}\text { kg. } \\
-2.0 \\
-1.6 \\
-1.6 \\
-2.5 \\
-1.9 \\
-3.0\end{array}$ & $\begin{array}{c}* \\
-5 \\
-8 \\
-6 \\
-10 \\
-4\end{array}$ & $\begin{array}{c}* \\
-21 \\
+2 \\
-6 \\
-9 \\
-16\end{array}$ & $\begin{array}{r}* \\
-16 \\
+10 \\
0 \\
+1 \\
-12\end{array}$ \\
\hline
\end{tabular}

* Repeatedly unsatisfactory.

to seventh days of the "rice diet." This infection coincided with a rise in his nitrogen excretion.

In Table VI are given the data on blood constituents. All subjects showed a decrease in serum cholesterol with an average fall of $44 \mathrm{mg}$. per 100 cc. Hemoglobin, hematocrit, and total protein showed a slight increase. The non-protein nitrogen was decreased in three subjects.

\section{DISCUSSION}

It is well known that dietary requirements vary with body size. The minimal daily nitrogen requirement for man on a mixed diet has been reported to be approximately $2.9 \mathrm{gm}$. per sq. m. of body surface $(6,7)$ or $5.2 \mathrm{gm}$. nitrogen $(32.5 \mathrm{gm}$. protein) for a man weighing $70 \mathrm{~kg}$. and with a surface area of 1.8 sq. $\mathrm{m}$. Calculated on this 
TABLE VI

Blood changes on rice diet

\begin{tabular}{|c|c|c|c|c|c|c|c|c|c|c|c|c|c|c|c|}
\hline & \multicolumn{3}{|c|}{$\begin{array}{l}\text { Cholesterol } \\
\text { mg. } / 100 \text { cc. }\end{array}$} & \multicolumn{3}{|c|}{$\begin{array}{l}\text { Total protein } \\
\mathrm{gm.} / 100 \mathrm{cc} .\end{array}$} & \multicolumn{3}{|c|}{$\begin{array}{l}\text { N.P.N. } \\
m g . / 100 c c .\end{array}$} & \multicolumn{3}{|c|}{$\begin{array}{l}\text { Hemoglobin } \\
\mathrm{gm} . / 100 \mathrm{cc.}\end{array}$} & \multicolumn{3}{|c|}{$\underset{\text { per cent }}{\text { Hematocrit }}$} \\
\hline & Initial & Final & Change & Initial & Final & Change & Initial & Final & Change & Initial & Final & Change & Initial & Final & Change \\
\hline $\begin{array}{l}1 \\
2 \\
3 \\
4 \\
5 \\
6\end{array}$ & $\begin{array}{l}165 \\
255 \\
275 \\
200 \\
185 \\
215\end{array}$ & $\begin{array}{l}150 \\
225 \\
175 \\
160 \\
130 \\
190\end{array}$ & $\begin{array}{r}-15 \\
-30 \\
-100 \\
-40 \\
-55 \\
-25\end{array}$ & $\begin{array}{l}7.8 \\
8.3 \\
5.9 \\
8.2 \\
8.1 \\
7.5\end{array}$ & $\begin{array}{l}8.3 \\
9.2 \\
7.8 \\
7.1 \\
9.2 \\
9.1\end{array}$ & $\begin{array}{r}+.5 \\
+.9 \\
+1.9 \\
-1.1 \\
+1.1 \\
+1.6\end{array}$ & $\begin{array}{l}38 \\
39 \\
41 \\
39 \\
35 \\
33\end{array}$ & $\begin{array}{l}29 \\
39 \\
32 \\
29 \\
35 \\
36\end{array}$ & $\begin{array}{r}-9 \\
0 \\
-9 \\
-10 \\
0 \\
+3\end{array}$ & $\begin{array}{l}14.2 \\
15.8 \\
15.6 \\
14.6 \\
14.2 \\
15.8\end{array}$ & $\begin{array}{l}15 \\
16 \\
15.8 \\
14.2 \\
15.4 \\
16.2\end{array}$ & $\begin{array}{r}+.8 \\
+.2 \\
+.2 \\
+.4 \\
+1.2 \\
+.4\end{array}$ & $\begin{array}{l}45 \\
46 \\
50 \\
43 \\
43 \\
48\end{array}$ & $\begin{array}{l}46 \\
49 \\
50 \\
44 \\
48 \\
51\end{array}$ & $\begin{array}{r}+1 \\
+3 \\
0 \\
+1 \\
+5 \\
+3\end{array}$ \\
\hline Av. & 216 & 172 & -44 & 7.6 & 8.4 & +0.8 & 38 & 33 & -5 & 15.0 & 15.4 & +.4 & 46 & 48 & +2 \\
\hline
\end{tabular}

basis, our subjects, with surface areas ranging from 1.69 to $2.00 \mathrm{sq}$. m., would require 4.87 to $5.80 \mathrm{gm}$. nitrogen (average 5.39) in a mixed diet.

For an average man ( $70 \mathrm{~kg} ., 1.8$ sq. m.) on a diet containing only vegetable protein the minimal nitrogen requirement has been found to be 4.8 to $7.9 \mathrm{gm}$. per day $(29.7-49.1 \mathrm{gm}$. protein) depending upon the protein used $(6,7)$. With diets containing rice as the major protein source the minimal requirement is even higher. Aron and Hocson (14) and Kumagawa (15) studying such diets reported that nitrogen balance could be achieved only when the daily nitrogen intake was no less than $0.18 \mathrm{gm}$. per $\mathrm{kg}$. body weight, or more than $12 \mathrm{gm}$. for a $70 \mathrm{~kg}$. man.

Urinary nitrogen excretion values as low as the $2.26 \mathrm{gm}$. per day reported by Kempner on the "rice diet" have been reported by other workers only on nitrogen-free, high caloric regimes (16, 17). On a nitrogen-free, high caloric diet the nitrogen excretion represents endogenous protein breakdown. The value obtained is a function of the energy metabolism and is generally accepted to be approximately $2.0 \mathrm{mg}$. nitrogen per basal calorie $(18,19,20)$. The average basal caloric expenditure for adult males in the age group 20 to 40 is 39.5 calories per sq. m. per hour (21). For an average male with a surface area of 1.8 sq. m., the daily basal caloric expenditure is 1,706 calories. At this metabolic level, the calculated endogenous nitrogen on the basis of $2 \mathrm{mg}$. per basal calorie is $3.4 \mathrm{gm}$. per day. In our five male normotensive subjects with an average surface area of 1.82 sq. $\mathrm{m}$. and an average basal caloric expenditure of 1,585 calories, the calculated endogenous nitrogen metabolism is $3.17 \mathrm{gm}$. Bricker et al. (6) have recently reported excretions of
$1.4 \mathrm{mg}$. per basal calorie. This figure would lower the calculated endogenous nitrogen metabolism for our subjects to $2.22 \mathrm{gm}$. per day, but it must be pointed out that studies on diets containing protein have not yielded such low figures $(6,7)$. In order to achieve balance, nitrogen intake must always be in excess of the endogenous nitrogen breakdown due to the fact that dietary proteins are not completely digested and utilized.

It is possible that even with the provision of 2,300 calories in our diet rather than the 2,000 calories used by Kempner, the caloric requirements of all of our subjects were not satisfied. The negative nitrogen balance, therefore, may be due at least in part to an inadequate caloric intake. It appears likely, however, that at least in those subjects with basal caloric expenditures of 1,418, 1,451 and 1,568 calories the caloric intake was adequate.

The loss of weight in all subjects cannot be completely accounted for by the negative nitrogen balance. The restricted salt and fluid intake were undoubtedly contributory factors. A third factor to be considered is the possible inadequacy of caloric intake. A similar excessive loss of weight has been noted by Eckhardt $e t$ al. (22) in subjects with adequate caloric intake but deficient protein intake.

It has been shown that on low protein test diets minimal urinary nitrogen excretion levels may be closely approached in three to four days, particularly if a preliminary protein depletion diet is employed $(7,23,24)$. After four days on the protein depletion diet and eight days on the "rice diet," all of our subjects were in negative nitrogen balance with a daily average excess of excretion over intake of $3.22 \mathrm{gm}$. Although the data on urinary nitrogen excretion suggest that 
the minimal level of excretion had not been achieved, the slope of the excretion curve indicates that this level was closely approximated (Figure 1). It thus seems unlikely that nitrogen balance can be attained on a Kempner regime providing $3.2 \mathrm{gm}$. nitrogen (20 gm. protein) per day. Even after 90 days on the "rice diet," the hypertensive patient showed essentially the same order of magnitude of negative nitrogen balance $(2.67 \mathrm{gm}$. per day) as was shown for the subjects in the shorter study. This patient had, at the start of the study, a basal caloric expenditure of 2,012 calories and lost weight rapidly for seven weeks (10 kg.). The weight loss during the last six weeks of the study was $2.7 \mathrm{~kg}$. At the time of final balance studies, the basal caloric expenditure was 1,663 calories.

There is no evidence to indicate that the "rice diet" has any unusual ability to satisfy the nitrogen demands of the body. In order to achieve nitrogen balance, it appears that nitrogen intake must be as high on this diet as on other diets consisting mainly of vegetable protein.

It is worthy of note that the hypertensive patient showed a marked clinical improvement on the Kempner regime although he failed to maintain nitrogen equilibrium. During the diet therapy, there was a significant drop in blood pressure and return to upright of $\mathrm{T}$-waves in the electrocardiogram. No fresh retinal hemorrhages oc-



Fig. 1. Urinary Nitrogen Excretions of Six Subjects on the Protein Depletion AND Rice Diets

Each subject is represented by a separate symbol. 
curred, and there was dramatic symptomatic relief of headaches, dizziness and malaise.

\section{SUMMARY AND CONCLUSIONS}

1. Nitrogen balance was studied in six normotensive subjects on the Kempner "rice diet," which, by analysis, was found to contain $2.63 \mathrm{gm}$. nitrogen per day.

2. After eight days on the "rice diet" (preceded by four days on a protein depletion diet) analyses of food, urinary and fecal nitrogen revealed that all subjects were in negative nitrogen balance. The excretion was greater than the intake by an average of $3.22 \mathrm{gm}$. nitrogen per day.

3. An additional subject, suffering from hypertension, was followed for 90 days on the "rice diet" and showed a negative nitrogen balance of $2.67 \mathrm{gm}$. per day.

4. The "rice diet" shows no unusual ability to satisfy the nitrogen requirements of the body.

\section{BIBLIOGRAPHY}

1. Kempner, W., Compensation of renal metabolic dysfunction. North Carolina M. J., 1945, 6, 61. Ibid., 1945, 6, 117.

2. Kempner, W., Some effects of rice diet treatment of kidney disease and hypertension. Bull. New York Acad. Med., 1946, 22, 358.

3. Kempner, W., Treatment of kidney disease and hypertensive vascular disease with rice diet. North Carolina M. J., 1944, 5, 273.

4. Dick, G. F., and Schwartz, W. B., Response of experimental hypertension to. a rice and fruit juice diet. Proc. Soc. Exper. Biol. \& Med., 1947, 65, 22.

5. Grollman, A., and Harrison, T. R., Effect of rigid sodium restriction on blood pressure and survival of hypertensive rats. Proc. Soc. Exper. Biol. \& Med., 1945, 60, 52.

6. Bricker, M., Mitchell, H. H., and Kinsman, G. M., The protein requirements of adult human subjects in terms of the protein contained in individual foods and food combinations. J. Nutrition, 1945, 30, 269.

7. Hegsted, D. M., Tsongas, A. G., Abbott, D. B., and Stare, F. J., Protein requirements of adults. J. Lab. \& Clin. Med., 1946, 31, 261.

8. Peters, J. P., and Van Slyke, D. D., Quantitative Clinical Chemistry. Volume II. Methods. The Williams and Wilkins Company, Baltimore, 1932.
9. Bloor, W. R., The determination of cholesterol in blood. J. Biol. Chem., 1916, 24, 227.

10. Sanford, A. H., Sheard, C., and Osterberg, A. E., The photelometer and its use in the clinical laboratory. Am. J. Clin. Path., 1933, 3, 405.

11. Hawk, P. B., Oser, B. L., and Summerson, W. H., Practical Physiological Chemistry. The Blakiston Company, Philadelphia, 1947.

12. Folin, O., and Wu, H., A system of blood analysis. J. Biol. Chem., 1919, 38, 81.

13. Bowes, A. deP., and Church, C. F., Food Values of Portions Commonly Used. College Offset Press, Philadelphia, 1946.

14. Aron, H., and Hocson, F., Rice as food: Investigation of the nitrogen and phosphorus metabolism on a diet consisting principally of rice and other vegetable foodstuffs. Phillipine J. Sc., 1911, 6, 361 .

15. Kumagawa, M., Vergleichende Untersuchungen über die Ernährung mit gemischter und rein vegetabilischer Kost mit Berücksichtigung des Eiweissbedarfes. Arch. f. path., Anat., 1889, 116, 370.

16. Deuel, H. J., Sandiford, I., Sandiford, K., and Boothby, W. M., A study of the nitrogen minimum. J. Biol. Chem., 1928, 76, 391.

17. Smith, M., The minimum endogenous nitrogen metabolism. J. Biol. Chem., 1926, 68, 15.

18. Terroine, E. F., and Sorg-Matter, H., Influence de la température extérieure sur la dépense azotée endogène des homéothermes. Arch. internat. de physiol., 1928, 30, 115.

19. Sorg-Matter, H., Loi quantitative de la dépense azotée minima des homéothermes, validité intraspécifique. Arch. internat. de physiol., 1928, 30, 126.

20. Smuts, D. B., The relation between the basal metabolism and the endogenous nitrogen metabolism, with particular reference to the estimation of the maintenance requirement of protein. J. Nutrition, 1935, 9, 403.

21. DuBois, E. F., Basal Metabolism in Health and Disease. Lea and Febiger, Philadelphia, 1927.

22. Eckhardt, R. D., Lewis, J. H., Murphy, T. L., Batchelor, W. H., and Davidson, C. S., Chemical, clinical and immunological studies on the products of human plasma fractionation. XXXIV. Comparative studies on the nutritive value of orally and intravenously administered human serum albumin in man. J. Clin. Invest., 1948, 27, 119.

23. Leitch, I., and Duckworth, J., The determination of the protein requirements of man. Nutrition Abstr. \& Rev., 1937, 7, 257.

24. Martin, C. J., and Robison, R., The minimum nitrogen expenditure of man and the biological value of various proteins for human nutrition. Biochem. J., 1922, 16, 407. 